\title{
Новые полимерные магнитные наноматериалы
}

\author{
Р. А. Дворикова К. Х. Н., В. А. Васнёв д. Х. Н., О. В. Баранов К. Х. Н., \\ Институт элементоорганических соединений \\ им. А. Н. Несмеянова РАН, Москва \\ rad@ineos.ac.ru
}

УДК 544.72 .05

Статья получена 10.10.2019

Принята к публикации 08.11.2019

\begin{abstract}
Предложен новый подход к получению магнитных наноматериалов путем термоструктурирования ферроценсодержащих полифениленов (ФПФ) и полихалконов (ФПХ). Максимальная намагниченность наноматериалов на основе ФПФ составила $32 \Gamma \mathrm{c} \cdot \mathrm{cm}^{3} /\left\ulcorner\right.$, а на основе ФПХ достигла $43 \Gamma \mathrm{c} \cdot \mathrm{cm}^{3} /\ulcorner$ в магнитном поле $2,5 \mathrm{~K} \ni$. По данным просвечивающей электронной микроскопии среднестатистические размеры магнитных частиц нанокомпозитов на основе ФПФ были от 6 до 22 нм, а на основе ФПХ - от 4 до 53 нм. Рентгенодифракционное исследование показало, что магнитные наноматериалы, полученные после прогрева ФПФ в интервале температур от 250 до $500{ }^{\circ} \mathrm{C}$, содержали, в основном, наночастицы магнетита $\left(\mathrm{Fe}_{3} \mathrm{O}_{4}\right)$, в то время как магнитные материалы, полученные после прогрева ФПХ при 500 и $1000{ }^{\circ} \mathrm{C}$, содержали 43 и $75 \%$ нульвалентного железа (FeO). По данным термогравиметрических испытаний потеря массы наноматериала из ФПФ в аргоне протекает преимущественно при температуре $600^{\circ} \mathrm{C}$, а наноматериала на основе $\Phi П X-$ в интервале от 700 до $1000^{\circ} \mathrm{C}$, масса твердого остатка составляет 85-95\% от первоначального.
\end{abstract}

Поиск и разработка новых магнитных наноматериалов, которые соответствуют требованиям передовых нанотехнологий, - одно из важных направлений современной науки [1-4]. Такие материалы используются в различных электронных и магнитных устройствах для записи информации, магнитной визуализации, доставки лекарственных препаратов, защиты от низкочастотных магнитных излучений и во многих других случаях.

Синтез органических соединений с магнитными свойствами, обусловленными их собственной структурой, особенно привлекателен, так как открывает возможность целенаправленного создания композитных материалов с заданными магнитными параметрами. В качестве прекурсоров полимеров с магнитными свойствами были синтезированы и исследованы ферроценсодержащие полифенилены (ФПФ) и ферроценсодержащие полихалконы (ФПХ).

Ранее был предложен новый оригинальный подход К получению наноразмерных композитов путем термоструктурирования ферроценсодержащих полифениленов реакционноспособными концевыми группами. В отличие от других многочисленных методов создания нанокомпозитов, в качестве прекурсора используется полимер, содержащий в своем составе равномерно распределенные элементы будущей новой фазы магнитного характера, которая проявляет свои свойства в процессе термолиза полимерной матрицы [5-9].

Ферроценсодержащие полимеры полифениленового типа (ФПФ) получали тримеризационной полициклоконденсацией ацетильных производных ферроцена в растворе, в присутствии триэтилортоформиата и кислого катализатора $[5,7,10]$ по схеме 1 (рис. 1).

Схема реакции идеализирована, так как в процессе синтеза, помимо замещенных бензольных фрагментов, образуются также $\beta$-метилхалконовые (дипноновые), поливиниленовые и другие дефектные фрагменты.

Полученные полимеры были охарактеризованы методами элементного анализа, ИК-и ЯМР-спектроскопии, рентгенодифракционным, просвечивающей электронной микроскопии (ПЭМ), сканирующей электронной микроскопии (СЭМ) и термогравиметрии (ТГА).

Магнитные наноматериалы получали путем нагревания образцов ФПФ в ампулах в ячейке магнитометра на воздухе при температуре $200-1000^{\circ} \mathrm{C}$, либо в токе аргона при температуре $250-500^{\circ} \mathrm{C}$.

Прогрев образцов приводил к дополнительному сшиванию полимерных молекул и сопровождался возникновением кристаллических железосодержащих магнитных 


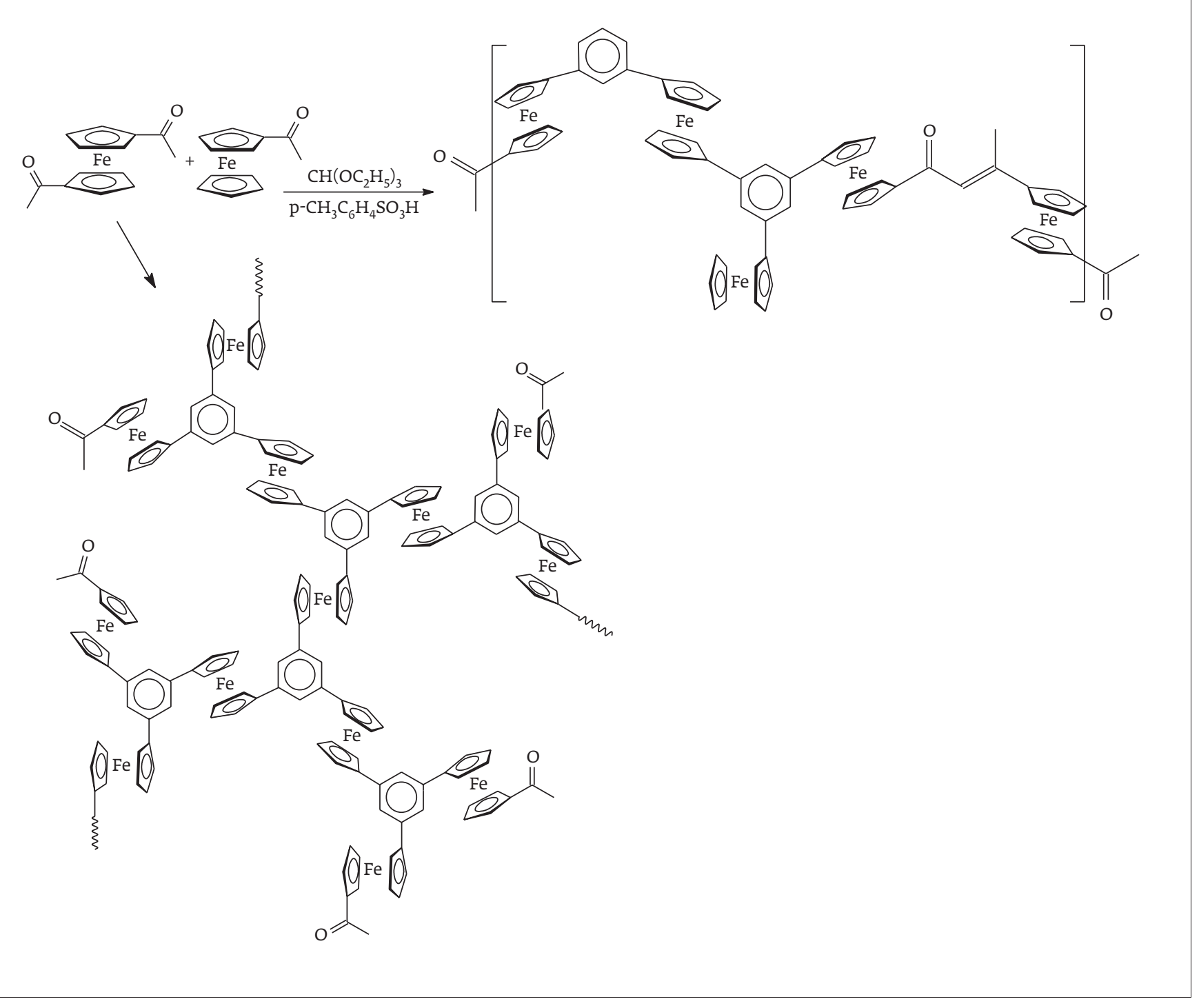

Puc. 1. Синтез ферроценсодержащих полимеров полифениленового типа (Схема 1)

наночастиц. Механизм их формирования включал твердофазное термическое превращение макромолекулярных ферроценсодержащих фрагментов, когда в одном процессе, наряду с образованием металлосодержащих наночастиц, одновременно происходила их стабилизация матрицей полимера. Можно выделить три основные стадии образования железосодержащих наночастиц: термический распад ферроценового фрагмента; образование и рост наночастиц; и сопровождающееся сшиванием полифенилена превращение деметаллизированных Ср-лигандов и бензольных колец в оболочку, стабилизирующую наночастицу.

После нагревания до 350-500 C (по данным ИК-спектроскопии) увеличивается количество тризамещенных бензольных фрагментов и исчезают дипноновые фрагменты и концевые группы. При дальнейшем нагревании намагниченность возрастает и не позволяет исследовать объекты методом ИК-спектроскопии. При нагревании до $1000^{\circ} \mathrm{C}$, судя по данным элементного и дифракционного анализов, в образце присутствует аморфный углерод. Образцы после термообработки сохраняют монолитность.

Появление магнетизма и исследование зависимости магнитных свойств от температуры нагревания проводили на вибрационном магнитометре типа Фонера в магнитном поле напряженностью 2,5 кЭ. Из зависимости намагниченности от температуры прогрева (рис. 2) видно, что образование магнитоупорядоченной фазы для ФПФ, синтезированного при температуре $110^{\circ} \mathrm{C}$, происходит уже при температуре $200^{\circ} \mathrm{C}$, и максимальная намагниченность составляет $26 \Gamma \mathrm{c} \cdot \mathrm{cm}^{3} /$ г.

Для образца ФПФ, синтезированного при температуре $140{ }^{\circ} \mathrm{C}$, образование магнитоупорядоченной фазы начинается при прогреве в магнитометре от $500{ }^{\circ} \mathrm{C}$, причем 


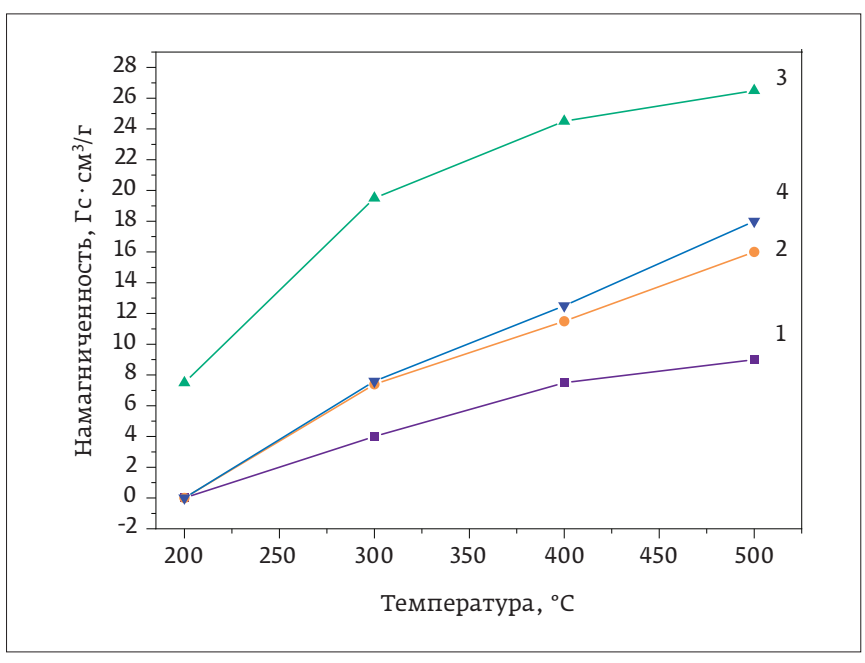

Puc. 2. Зависимость намагниченности от температуры прогрева дия ФПФ, синтезированных при $70-120^{\circ} \mathrm{C}: 1-70^{\circ} \mathrm{C} ; 2-100^{\circ} \mathrm{C}$;

$3-110^{\circ} \mathrm{C} ; 4-120^{\circ} \mathrm{C}$

в интервале температур 600-700 $\mathrm{C}$ происходит скачкообразный рост намагниченности насыщения, и при $800^{\circ} \mathrm{C}$ она достигает максимального значения - $32 Г c \cdot \mathrm{cm}^{3} / г$ (рис. 3). По данным ПЭМ, в прогретых образцах присутствуют равномерно распределенные в матрице полимера железосодержащие наночастицы со среднестатистическим размером от 6 до 26 нм, который зависит от условий синтеза и температуры прогрева [7].

Состав полученных наночастиц исследовали с помощью рентгенодифракционного анализа. На рис. 4 приведены рентгенодифракционные спектры образцов, синтезированных в обычных и сверхкритических условиях в $\mathrm{CO}_{2}$ после

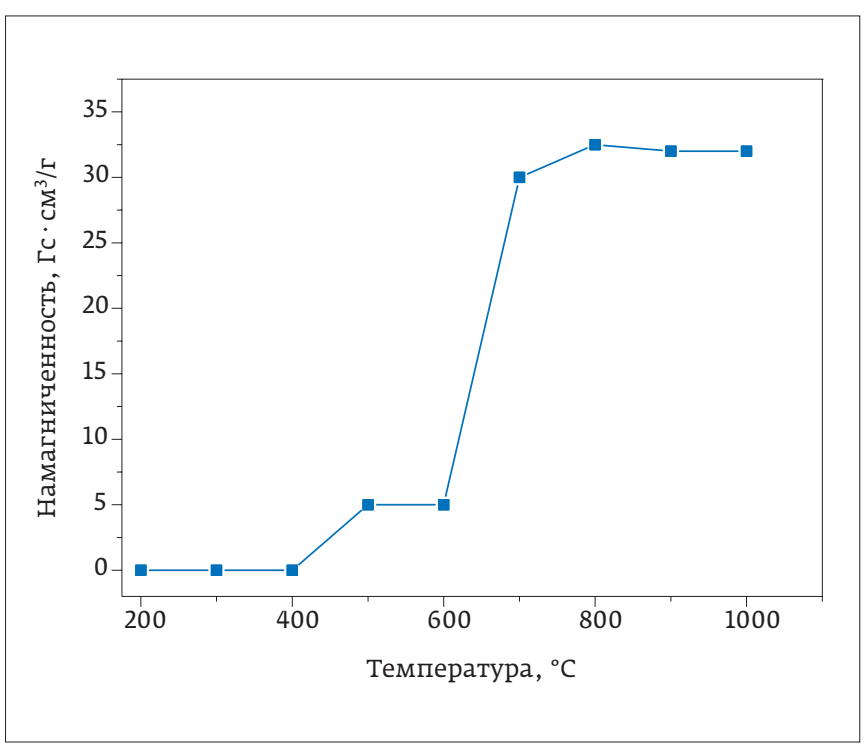

Puc. 3. Зависимость намагниченности от температуры прогрева для ФПФ, синтезированного при $140^{\circ} \mathrm{C}$

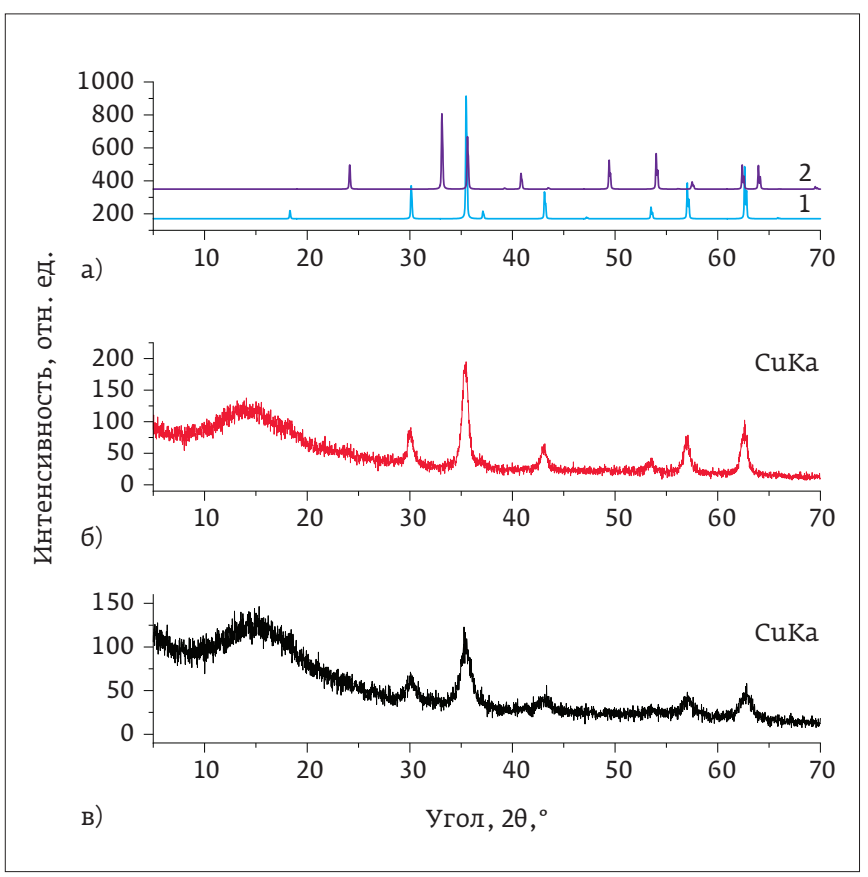

Puc. 4. Рентгенодифракционные спектры (а) оксидов железа $7-\mathrm{Fe}_{3} \mathrm{O}_{4} ; 2-\mathrm{Fe}_{2} \mathrm{O}_{3}$. И для образцов ФПФ, прогретых при $250{ }^{\circ} \mathrm{C}$, синтезированных в обычных условиях (6) и в $\mathrm{CK}^{-\mathrm{CO}_{2}}$ (в)

прогрева при $250{ }^{\circ} \mathrm{C}$, и модельные спектры двух оксидов железа $\left(\mathrm{Fe}_{3} \mathrm{O}_{4}\right.$ и $\left.\mathrm{Fe}_{2} \mathrm{O}_{3}\right)$.

На рис. 4 спектры 6 и в показывают полное совпадение экспериментальных данных с модельным спектром $\mathrm{Fe}_{3} \mathrm{O}_{4}$ (спектр 1 рис. 4а). Видно, что в образцах присутствует единственная кристаллическая фаза - магнетит $\mathrm{Fe}_{3} \mathrm{O}_{4}$. Помимо кристаллической,

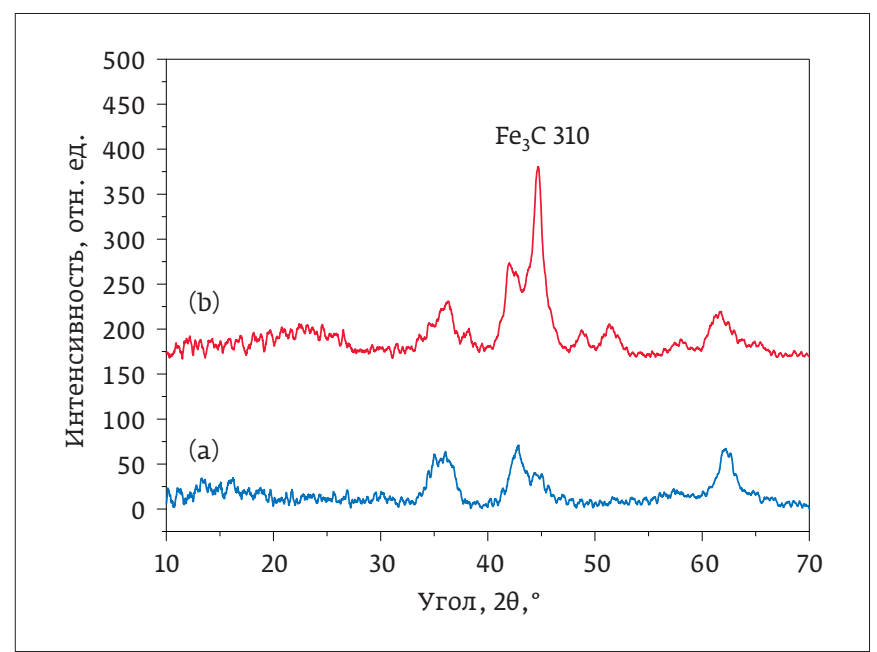

Puc. 5. Дифрактограмма образцов ФПФ, прогретых в ячейке магнитометра при 600 (а) и $675^{\circ} \mathrm{C}(6)$, с вычтенным фоном Обозначена наиболее интенсивная пиния цементита, остальные минии отвечают вюститу и магнетиту 
Таблица 1. Результаты прогрева ФПФ при температурах от 250 до $1000^{\circ} \mathrm{C}$

\begin{tabular}{|c|c|c|c|c|c|c|c|}
\hline № & $\begin{array}{c}\text { Темпе- } \\
\text { ратура, }\end{array}$ & $\begin{array}{c}\text { Продолжи- } \\
\text { тельность, } \\
\text { 'С }\end{array}$ & $\begin{array}{c}\text { Выход, } \\
\%\end{array}$ & $\begin{array}{c}\text { Намагни- } \\
\text { ченность, } \\
\text { Гс·см /г }\end{array}$ & \multicolumn{3}{|c|}{ Элементный состав, \% } \\
\hline 1 & 250 & 1 & 76 & Слабая & 66,51 & 4,86 & 20,69 \\
\hline 3 & 500 & 2 & 71 & 4,5 & 67,45 & 4,71 & 19,80 \\
\hline 4 & 700 & 1 & 69 & 31,8 & 70,70 & 1,23 & 20,30 \\
\hline 5 & 1000 & 1 & 65 & 32,0 & 71,55 & 0,88 & 21,40 \\
\hline
\end{tabular}
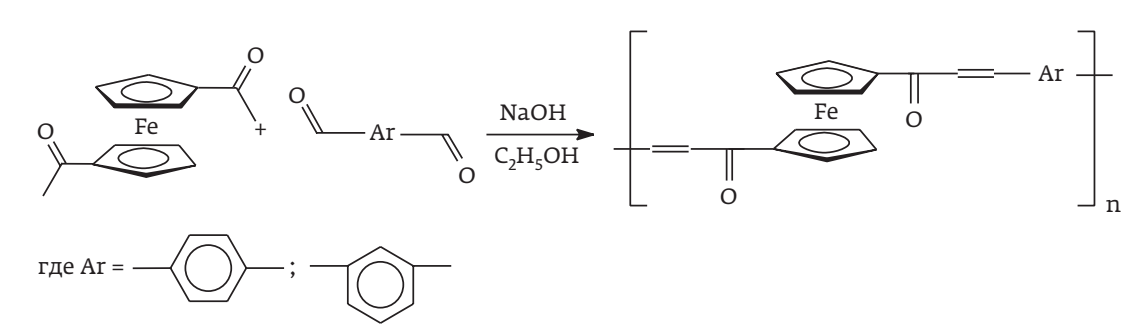

Puс. 6. Получение ферроценсодержащих полихалконов (Схема 2)

в значительном количестве находится аморфная фаза, что подтверждается диффузным гало в области $2 \theta$ при 10-20 ㄷ․ Для всех исследованных ФПФ, термоструктурированных при 250-500 들, состав наночастиц был одинаковым.

С повышением температуры прогрева выше $500^{\circ} \mathrm{C}$ состав становился более сложным (рис. 5). Образцы после прогрева при 600-675 ${ }^{\circ} \mathrm{C}$ состояли не только из магнетита $\left(\mathrm{Fe}_{3} \mathrm{O}_{4}\right)$, но и цементита $\left(\mathrm{Fe}_{3} \mathrm{C}\right)$ и вюстита $\left(\mathrm{Fe}_{0,97} \mathrm{O}\right)$. Так образец ФПФ, прогретый при $600{ }^{\circ} \mathrm{C}$, содержал $43 \% \mathrm{Fe}_{3} \mathrm{O}_{4}, 25 \% \mathrm{Fe}_{3} \mathrm{C}$ и 32\% $\mathrm{Fe}_{0,97} \mathrm{O}$. С повышением температуры до $675^{\circ} \mathrm{C}$ содержание магнетита уменьшалось до $11 \% \mathrm{Fe}_{3} \mathrm{O}_{4}$, а цементита и вюстита увеличивалось до 64\% $\mathrm{Fe}_{3} \mathrm{C}$ и $25 \% \mathrm{Fe}_{0,97} \mathrm{O}$.

Проведено исследование влияния прогрева синтезированных ФПФ при различных температурах на выход и элементный состав полученных наноматериалов. Результаты приведены в табл. 1. Выход наноматериалов с ростом температуры прогрева уменьшается, но даже при температуре $1000{ }^{\circ} \mathrm{C}$ составляет 65\%. Намагниченность образцов увеличивается, содержание углерода возрастает до 71,55\%, а водорода - уменьшается.

Термические свойства ФПФ исследовали методом ТГА (рис. 7). Исследованы два прогретых при $500{ }^{\circ} \mathrm{C}$ образца: один - в атмосфере аргона в течение 2 ч, другой после прогрева в ячейке магнитометра. Из рис. 7 видно, что температурная область термического разложения для них одинакова, и потеря массы протекает преимущественно в области $600^{\circ} \mathrm{C}$. Однако для образца, прогретого в аргоне, наблюдается большее количество твердого остатка и отсутствует потеря массы в области низких температур. Это указывает на формирование более плотной сетчатой структуры при его термической обработке в таких условиях.

Другой тип прекурсоров - ферроценсодержащие полихалконы (ФПХ) получали взаимодействием 1,1'-диацетилферроцена с тере- или изофталевым альдегидом в спиртовом растворе в присутствии щелочи [11] по схеме 2 (рис. 6).

Полученные полимеры представляют собой порошки бордового цвета, которые не плавятся и растворимы или ограниченно растворимы в некоторых органических растворителях. На рис. 8 приведены кривые намагниченности синтезированных ФПХ в зависимости от температуры их прогрева от 200 до $1000^{\circ} \mathrm{C}$. Образцы начинают проявлять магнитные свойства при температуре выше 500 и $600^{\circ} \mathrm{C}$ и достигают $43 Г \mathrm{c} \cdot \mathrm{cm}^{3} /$ г при $1000{ }^{\circ} \mathrm{C}$ в магнитном поле напряженностью 2,5 кЭ. Следует подчеркнуть, что при прогреве до $1000{ }^{\circ} \mathrm{C}$ образцы обладают высокой намагниченностью в интервале 39-43Гс $\mathrm{cm}^{3} /$ г.

Данные ПЭМ показали, что формирование железосодержащих наночастиц размером 3-6 нм начинается в процессе прогрева ФПХ при $500^{\circ} \mathrm{C}$, причем кристаллические наночастицы равномерно распределены в полимерной матрице. С увеличением температуры одновременно возрастает

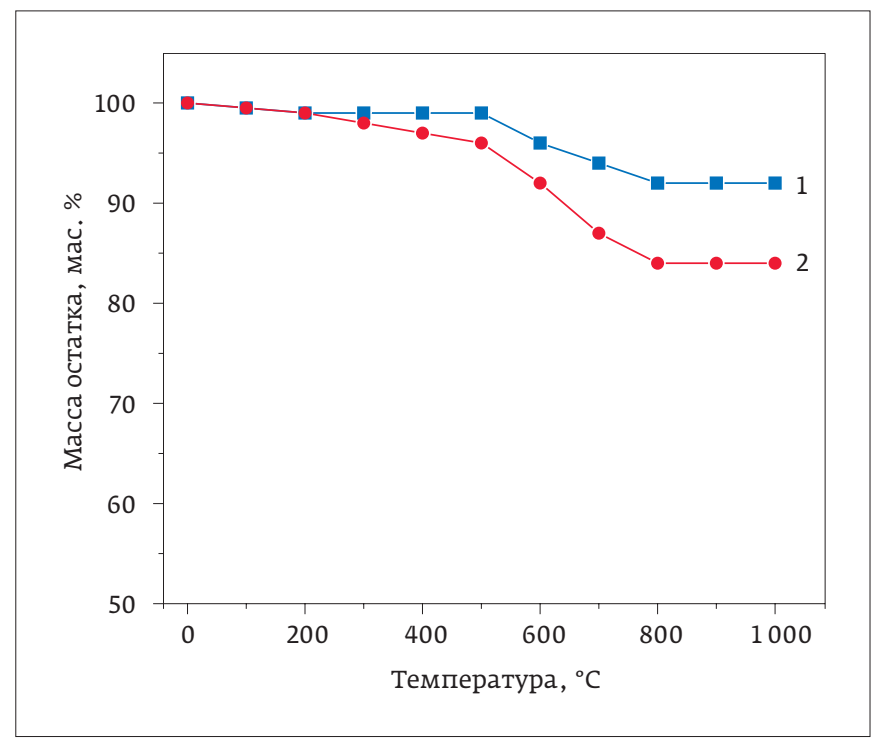

Puc. 7. Кривые ТГА для магнитных образиов ФПФ после прогрева при $500^{\circ} \mathrm{C}$ в атмосфере аргона (1) и в измерительной ячейке мaгнuтометра (2) 


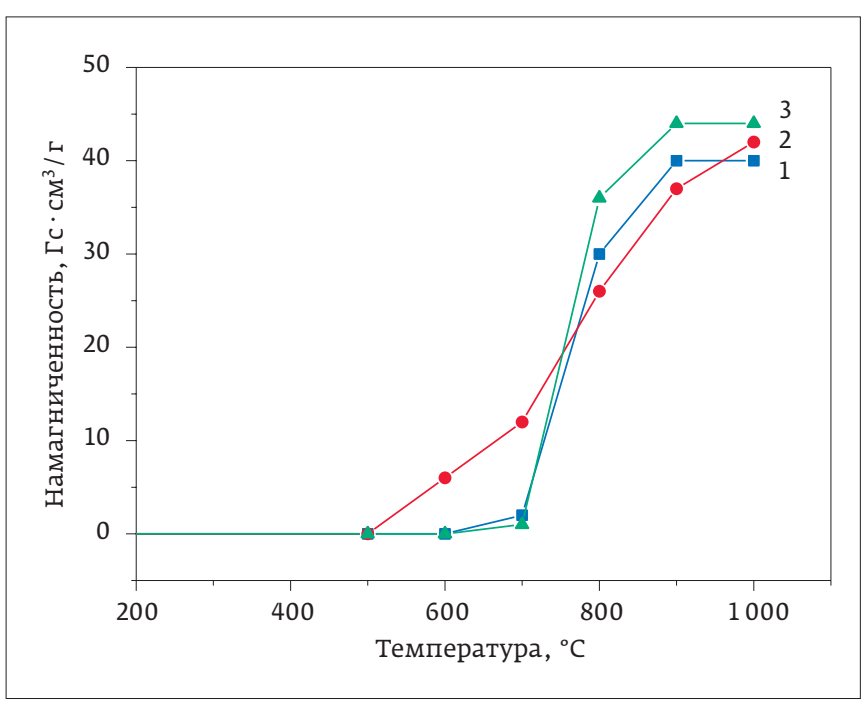

Puc. 8. Зависимость намагниченности от температуры прогрева для ФПХ, синтезированных при $20-70^{\circ} \mathrm{C}$ : где $7-70^{\circ} \mathrm{C}, 2-20^{\circ} \mathrm{C}, 3-40^{\circ} \mathrm{C}$

до 53 нм среднестатистический размер наночастиц и намагниченность материала.

Установлено, что полученный материал имеет структуру "ядро - оболочка - матрица" (рис. 9), где ядром являются железосодержащие наночастицы, в которых преобладает железо в нульвалентном состоянии $\left(\mathrm{Fe}^{0}\right)$. Их покрывает оболочка из уплотненного графита, а матрица состоит из терморасширенного графита.

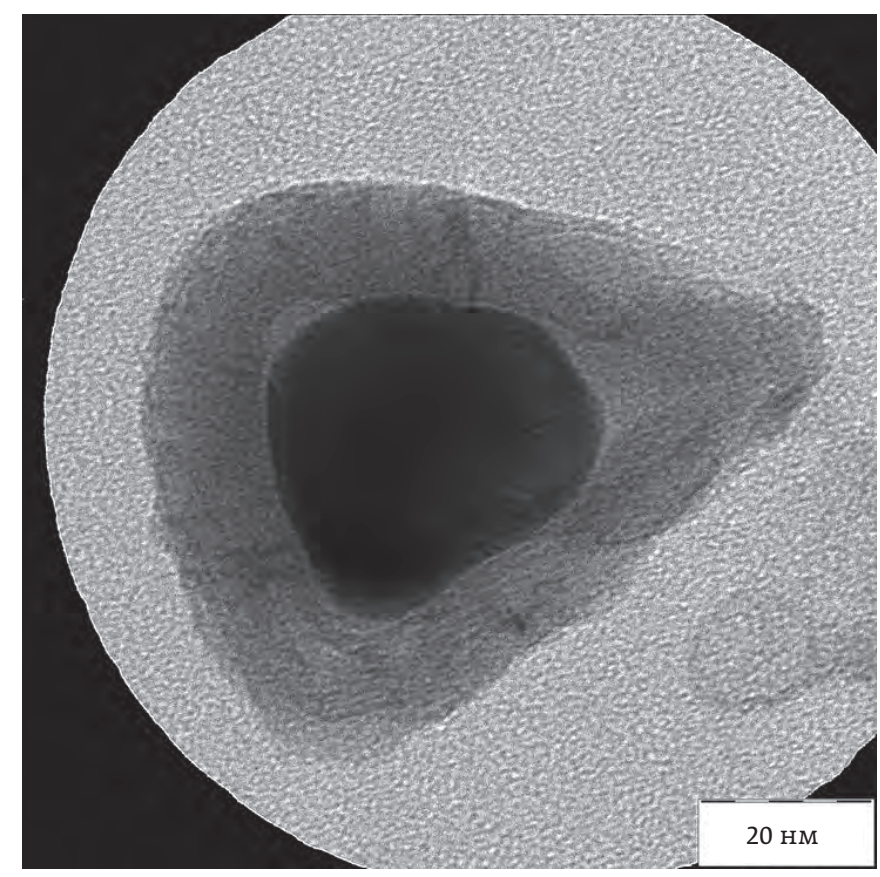

Puc. 9. Микрофотография наночастицы железа в оболочке из уплотненного графита в матрице из терморасширенного графита для образиа ФПХ после прогрева при $800^{\circ} \mathrm{C}$ в течение 74
Микрофотография электронной дифракции (рис. 10) подтверждает кристаллическую структуру наночастицы (в основном нульвалентного железа) и кристаллического графита.

Рентгенодифракционное исследование (рис. 11) показало, что магнитный наноматериал, полученный из ФПХ при $700{ }^{\circ} \mathrm{C}$, состоит из 43 масс.\% нульвалентного железа и 57 масс.\% графита. В магнитном материале, полученном при прогреве ФПХ при $800^{\circ} \mathrm{C}$ (рис. 11), содержание нульвалентного железа в сумме всех железосодержащих включений составляет 75\%. Этот образец также содержит в небольших количествах магнетит, гематит и графит (5\% гематита, 16\% магнетита и 10\% графита).

Термическая и термоокислительная стабильность наноматериала изучена методом ТГА (рис. 12) на примере образца с намагниченностью 26,5 Гс·см³/ г, полученного путем прогрева ФПХ в ячейке магнитометра при $800{ }^{\circ} \mathrm{C}$ в течение 1 ч. Из рис. 12 следует, что разложение такого образца на воздухе проходит через стадию окисления, сопровождающуюся набором массы в области $400{ }^{\circ} \mathrm{C}$ за счет присоединения молекул кислорода. Термоокислительная деструкция заканчивается вблизи $700{ }^{\circ} \mathrm{C}$, и масса твердого остатка составляет величину порядка 33\% первоначальной. При нагревании в аргоне образец характеризуется гораздо более высокой термической стабильностью и начинает незначительно терять массу в области $700{ }^{\circ} \mathrm{C}$, и при $1000^{\circ} \mathrm{C}$ масса твердого остатка близка к 95\%.

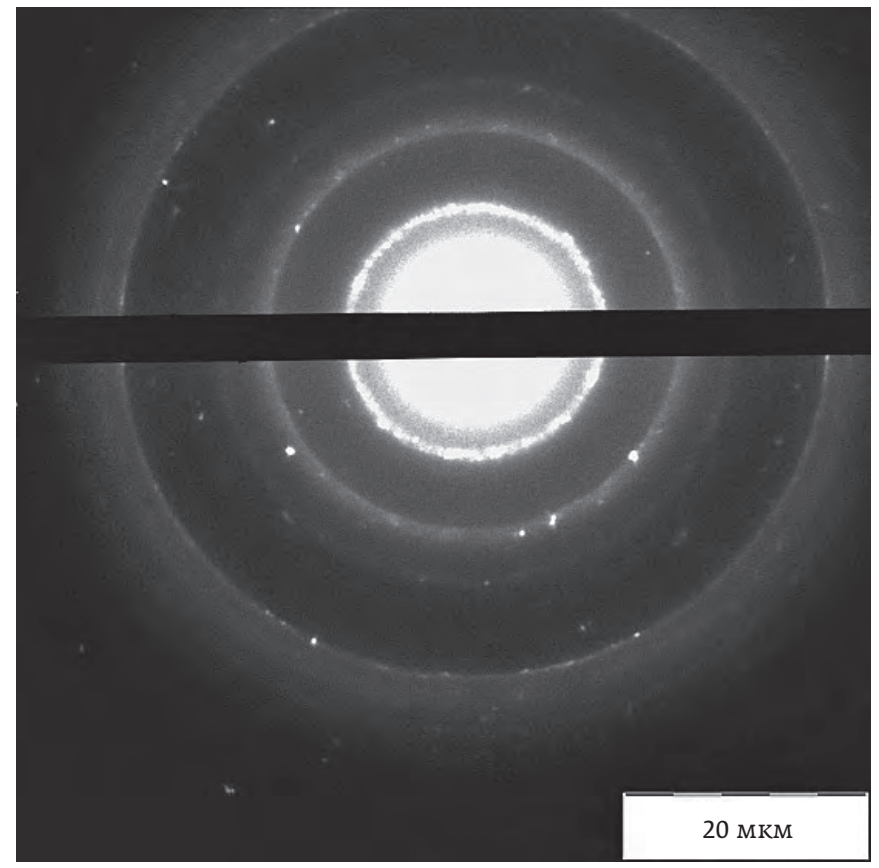

Puc. 10. Картина дифракции электронов на покальном участке (оболочка из графита размером 10-15 нм) образиа ПХ после прогрева при $800^{\circ} \mathrm{C}$ в течение 74 


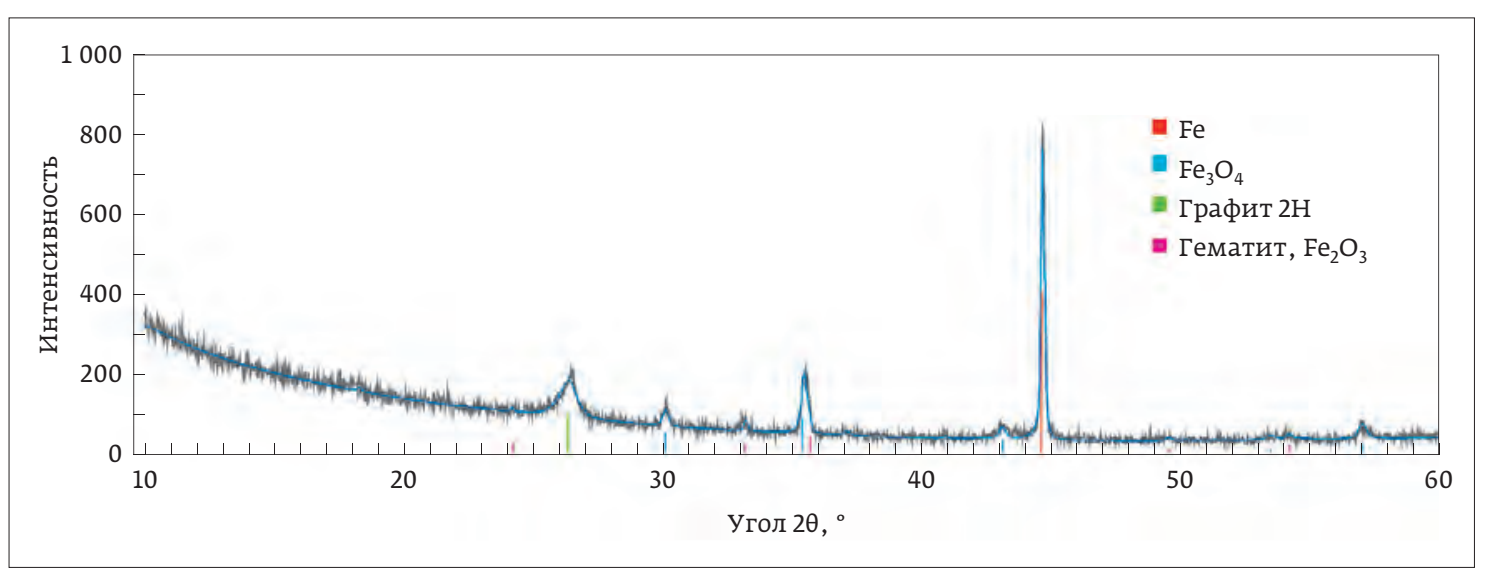

Puc. 11.

Дифрактограмма образиа ФПх после прогрева при $800^{\circ} \mathrm{C}$ в течение 74

Таким образом, в результате проведенных исследований получены новые магнитные наноматериалы на основе ФПФ и ФПХ. Определены среднестатистические размеры наночастиц (4-53 нм), содержащихся в матрице структурированного полимера. Показана принципиальная возможность контроля размера и состава наночастиц, а также их намагниченности, в зависимости от условий получения и температуры структурирования полимеров.

Работа выполнена при поддержке Министерства науки и высшего образования Российской Федерации с использованием научного оборудования Центра исследования строения молекул ИНЭОС РАН.

\section{ЛИТЕРАТУРА}

1. Помогайло А. Д., Розенберг А. С., Уфлянд И. Е. Наночастицы металлов в полимерах. - М.: Химия, 2000, 672 С.

2. Губин С. П., Кокшаров Ю. А., Хомутов Г. Б., Юрков Г. Ю. Магнитные наночастицы: методы получения, строение и свойства // Успехи химии 2005. T. 74, C. 539-574.

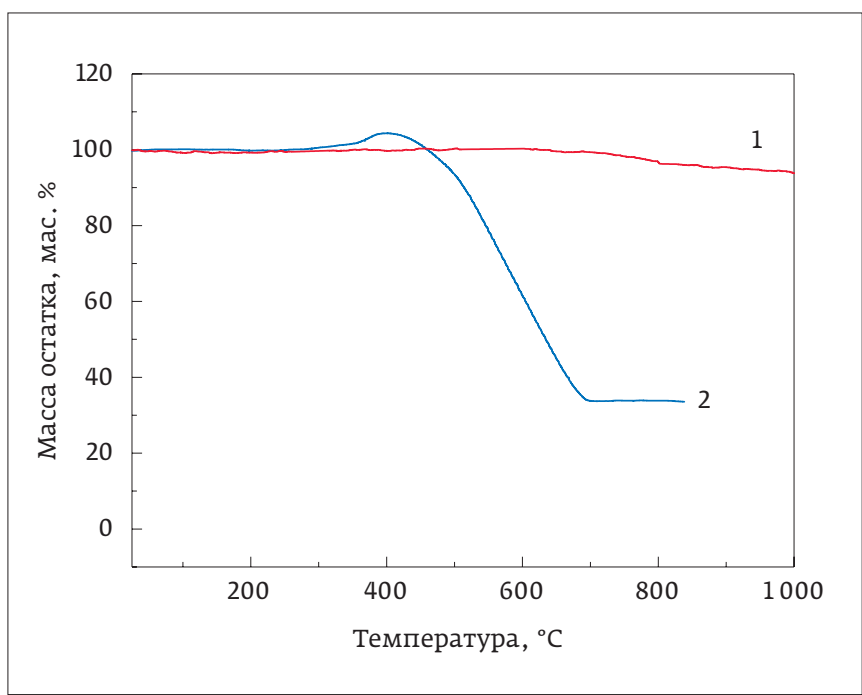

Puc. 12. Кривые ТГА в аргоне (1) и на воздухе (2) магнитного образиа, полученного путем прогрева ФПХ при $800^{\circ} \mathrm{C}$ в ячейке магнитометра
3. Gudoshnikov S., Liubimov B., Matveets L., Ranchinski M., Usov N., Gubin S., Yurkov G., Snigirev O., Volkov I. Magnetic properties of Fe-based nanoparticle assembly // Journal of Magnetism and Magnetic Materials. 2003. V. 259. P. 54-56.

4. Koichiro Hayashi, Wataru Sakamoto, Toshinobu Yogo. Magnetic and rheological properties of monodisperse $\mathrm{Fe}_{3} \mathrm{O}_{4}$ nanoparticle/ organic hybrid // Journal of Magnetism and Magnetic Materials. 2009. V. 321. № 5. P. 450-457.

5. Dvorikova R.A, Antipov B.G., Klemenkova Z.S., Shanditsev V.A., Prokof'ev A. I., Petrovskii P. V., Rusanov A.L, Korshak Yu. V. Synthesis and investigation of electromagnetic properties of new ferrocene-containing polyphenylenes. Polymer Science. 2005. Ser. A. Vol. 11. P. 1135-1140.

6. Dvorikova R.A., Nikitin L. N., Korshak Yu.V., Shanditsev V.A., Rusanov A.L., Abramchuk S.S., Khokhlov A.R. New magnetic nanomaterials based on hyperbranched ferrocene-containing polyphenylenes synthesized in sub- and supercritical carbon dioxide // Doklady Chemistry. 2008. V. 422. P. 231-235.

7. Dvorikova R.A., Nikitin L. N., Korshak Yu. V., Buzin M.I., Shanditsev V. A., Koryukov A. A., Bushmarinov I. S., Abramchuk S. S., Rusanov A.L., Khokhlov A. R. Ferrocene-containing polyphenylenes as precursors of magnetic nanomaterials // Nanotechnologies in Russia. 2010. V. 5. P. 647-655.

8. Дворикова Р.А., Коршак Ю.В., Никитин Л.Н., Шандицев В.А., Бузин М. И., Клеменкова 3.С., Коварский А. Л., В. В. Каспаров В. В. Некоторые физико-химические и магнитные характеристики нанокомпозитов на основе ферроценсодержащих полимеров // Новое в полимерах и полимерных композитах. 2012. № 2. С. 79-85.

9. Dvorikova R.A, Korshak Yu.V., Nikitin L.N., Buzin M. I., Shanditsev V.A., Klemenkova Z.C., Rusanov A.L., Khokhlov A.R., Lappas A., Kostopoulou A. New magnetic nanoparticles in polymers // Engineering of Polymers and Chemical Complexity. New Approaches, Limitations, and Control. Edited by Walter W. Focke, PhD and Hans-Joachim Radusch, PhD, Gennady E. Zaikov, DSC, and A. K. Haghi, Ph D. Apple Academic Press. Inc. 2014. V. 2. Chapter 7. Toronto New jersey. P. 145-160.

10. Dvorikova R.A., Peregudov A.S., Korlyukov A.A, Buzin M.I., Nagornova I.V., Vasnev V.A. New magnetic nanomaterials based on ferrocene-cotaining polymers synthesized under ultrasonic irradiation // Russian Chemical Bulletin, International Edition. 2019. V.68. № 7. Р. 1435-1440.

11. Дворикова Р.А., Коршак Ю.В., Никитин Л.Н., Бузин М.И., Корлюков А.А., Благодатских И.В., Клеменкова 3.С., Абрамчук С. С., Васнёв В.А. Магнитный наноматериал на основе ферроценсодержащих полихалконов и способ его получения. - Патент Российской Федерации RU2665055 Cl, 2018. Бюлл. № 25.

\section{REFRENCES}

1. Helped A. D., Rosenberg A.S., Uflyand I. E. Nanoparticles of Metals in Polymers: Moscow. Khimiya-Chemistry publ. 2000, 672 p.

2. Gubin S. P., Koksharov Yu.A., Khomutov GB, Yurkov G. Yu. Magnetic Nanoparticles: Production Methods, Structure and Properties. Uspekhi Khimii.(Russian Chtmical Reviews). 2005. V. 74, pp. 539-574. 
3. Gudoshnikov S., Liubimov B., Matveets L., Ranchinski M., Usov N., Gubin S., Yurkov G., Snigirev O., Volkov I. Magnetic Properties of Fe-based Nanoparticle Assembly. Journal of Magnetism and Magnetic Materials. 2003. V. 258-259, pp.54-56.

4. Koichiro Hayashi, Wataru Sakamoto, Toshinobu Yogo. Magnetic and Rheological Properties of Monodisperse $\mathrm{Fe}_{3} \mathrm{O}_{4}$ Nanoparticle/Organic Hybrid. Journal of Magnetism and Magnetic Materials. 2009. V. 321, no. 5 , March. pp. 450-457.

5. Dvorikova R. A., Antipov B.G., Klemenkova Z.S., Shanditsev V.A. Prokof'ev A.I., Petrovskii P. V., Rusanov A.L., and Korshak Yu. V. Synthesis and investigation of electromagnetic properties of new ferrocene-containing polyphenylenes. Polymer Science, 2005. Ser. A. V. 11, pp. 1135-1140

6. Dvorikova R.A., Nikitin L. N., Korshak Yu.V., Shanditsev V.A. Rusanov A.L., Abramchuk S.S., Khokhlov A.R. New magnetic nanomaterials based on hyperbranched ferrocene-containing polyphenylenes synthesized in sub- and supercritical carbon dioxide. Doklady Chemistry. 2008. V. 422. Part 1, pp. 231-235.

7. Dvorikova R.A., Nikitin L. N., Korshak Yu. V., Buzin M.I., Shanditsev V. A., Koryukov A. A., Bushmarinov I. S., Abramchuk S. S., Rusanov A.L., Khokhlov A. R. Ferrocene-containing polyphenylenes as precursors of magnetic nanomaterials. Nanotechnologies in Russia. 2010 V. 5, pp. 647-655.
8. Dvorikova R.A., Korshak Yu.V., Nikitin L. N., Shanditsev V.A., Buzin M. I., Klemenkova Z.S., Kovarsky A. L., Kasparov V.V. Some Physicochemical and Magnetic Characteristics of Nanocomposites Based on Ferrocene-containing Polymers. New in polymers and polymer composites. 2012, no. 2. pp. 79-85.

9. Dvorikova R.A., Korshak Yu.V., Nikitin L. N., Buzin M.I., Shanditsev V.A., Klemenkova Z.C., Rusanov A. L., Khokhlov A.R., Lappas A., Kostopoulou A. New Magnetic Nanoparticles in Polymers. Engineering of Polymers and Chemical Complexity. New Approaches, Limitations, and Control. Edited by Walter W. Focke, PhD and HansJoachim Radusch, PhD, Gennady E. Zaikov, DSc, and A. K. Haghi, PhD: Apple Academic Press, Inc. 2014, Volume 2. Chapter 7, Toronto New Jersey, pp. 145-160

10. Dvorikova R.A., Peregudov A.S., Korlyukov A.A., Buzin M.I., Nagornova I. V., Vasnev V.A. New magnetic nanomaterials based on ferrocene-cotaining polymers synthesized under ultrasonic irradiation. Russian Chemical Bulletin, International Edition. 2019. V. 68, no. 7, pp. 14351440.

11. Dvorikova R.A., Korshak Yu.V., Nikitin L.N., Buzin M.I. Korlyukov A. A., Blagodatskikh I. V., Klemenkova Z. S., Abramchuk S.S., Vasnev V.A. Magnetic Nanomaterial Based on Ferrocene-containing Polyhalcones and a Method for its Preparation: - Pat RU2665055 Cl, 2018. Bull. no 25

\section{КАК КРУПНЕЙШАЯ В МИРЕ ЖЕОДА ВЫРОСЛА ДО РАЗМЕРОВ ПОЛОВИНЫ МАЛЕНЬКОЙ СПАЛЬНИ?}

Большинство жеод - полых камней с кристаллами - могут поместиться в нашей ладони. Но и среди них есть исполины - гигант Pulpí Ceode, по размерам раза в два меньший небольшой спальни, заполняет часть заброшенной шахты в юго-восточной Испании. Исследователи проанализировали некоторые из его кристаллов

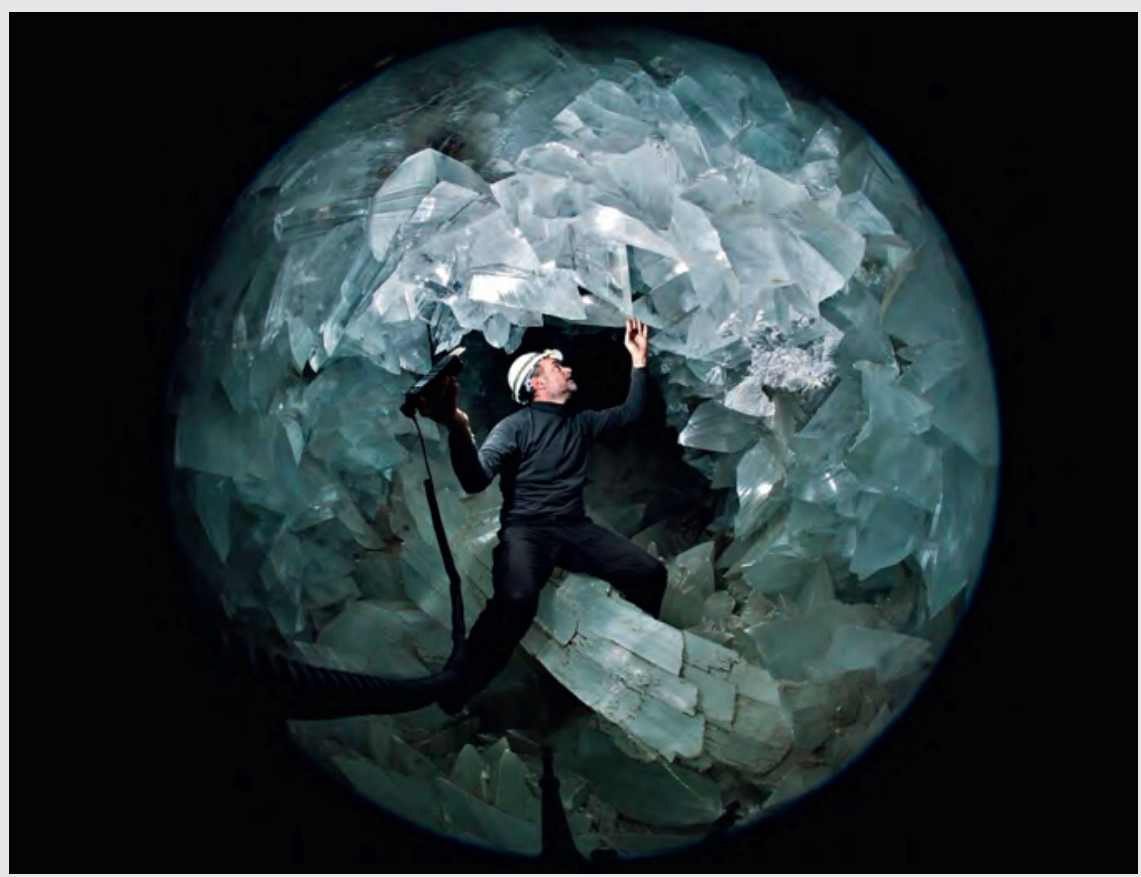

города. Некоторые из кристаллов имеют длину несколько метров и настолько чисты, что сохранили прозрачность, несмотря на свою значи тельную толщину.

Хотя жеода находится в породах во3растом около 250 миллионов лет, сами кристаллы жеоды намного моложе этого возраста. Радиоуглеродный анализ некоторых из самых старых из них показал, что они образовались не ранее 5,6 миллионов лет назад, но не позднее 2 миллионов лет назад, сообщают исследователи жеоды.

Хотя пещера в настоящее время сухая, во время роста жеоды ее полость была заполнена горячей, богатой минералами водой. Самый старый слой кристаллов, в состав которого входит минерал барит (сульфат бария), образовался при температуре около $100{ }^{\circ} \mathrm{C}$. Последующие слои, в которые входят кристаллы целестина (сульфата стронция), росли в водах при температуре примерно $70^{\circ} \mathrm{C}$. Самые молодые кристаллы гипса (гидратированного сульфата кальция) образовались при температуре около $20{ }^{\circ} \mathrm{C}$ по крайней мере 60000 лет назад - задолго до самого холодного периода последнего ледникового периода.

Источник: www.sciencemag.org 


\section{КОМПОЗИТ-ЭКСПО}

Тринадцатая международная специализированная выставка

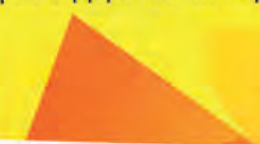

\section{Основные разделы выставки:}

- Сырье для производства композитных материалов, компоненты:

смолы, добавки, термопластики, углеродное волокно и т.д.

- Наполнители и модификаторы

- Стеклопластик, углепластик, графитопластик, базальтопластик,

базальтовые волокна, древесно-полимерный композит (ДПК), т.д.

- Полуфабрикаты (препреги)

- Промышленные (готовые) изделия из композитных материалов

- Технологии производства композитных материалов со

специальными и заданными свойствами

- Оборудование и технологическая оснастка для производства

композитных материалов

- Инструмент аля обработии композитных материалов

- Измерительное и испытательное оборудование

- Сертификация, технический регламент

- Компьютерное моделирование

-Утилизация

С. КЛЕИиальный раздел выставки:

Информационная поддержка:

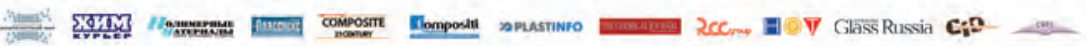

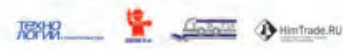
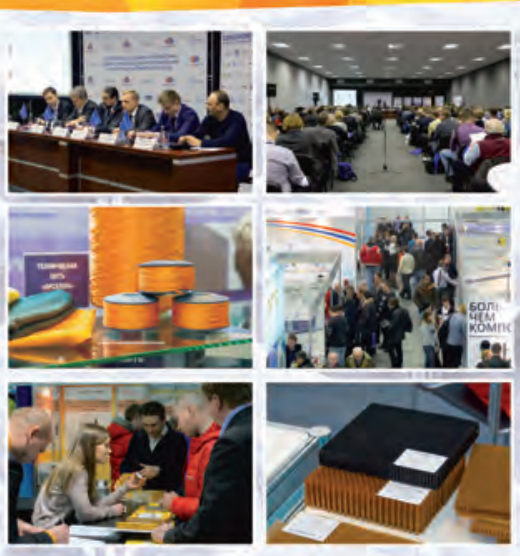

\section{1 - 23 апреля 2020}

Москва, ЦВК «Экспоцентр», пав. 1

\section{Дирекция:}

Выставочная Компания «Мир-Экспо»

115230, Россия, Москва, Хлебозаводский проезд, дом 7, строение 10, офис 507

Тел.: 8495 988-1620 | E-mail: info@composite-expo.ru | Сайт: www.composite-expo.ru

YouTube youtube.com/user/compoexporussia_ @compoexporus
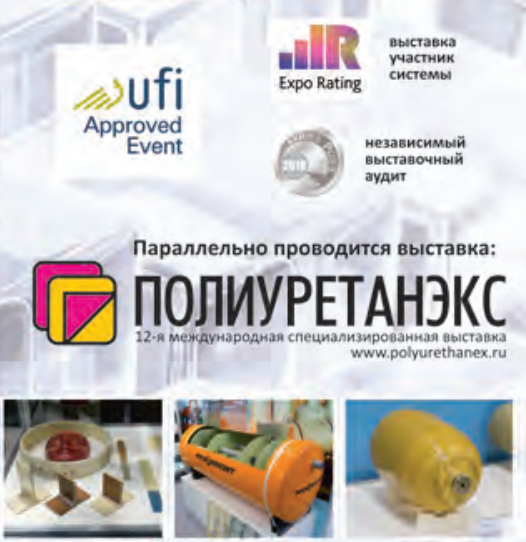
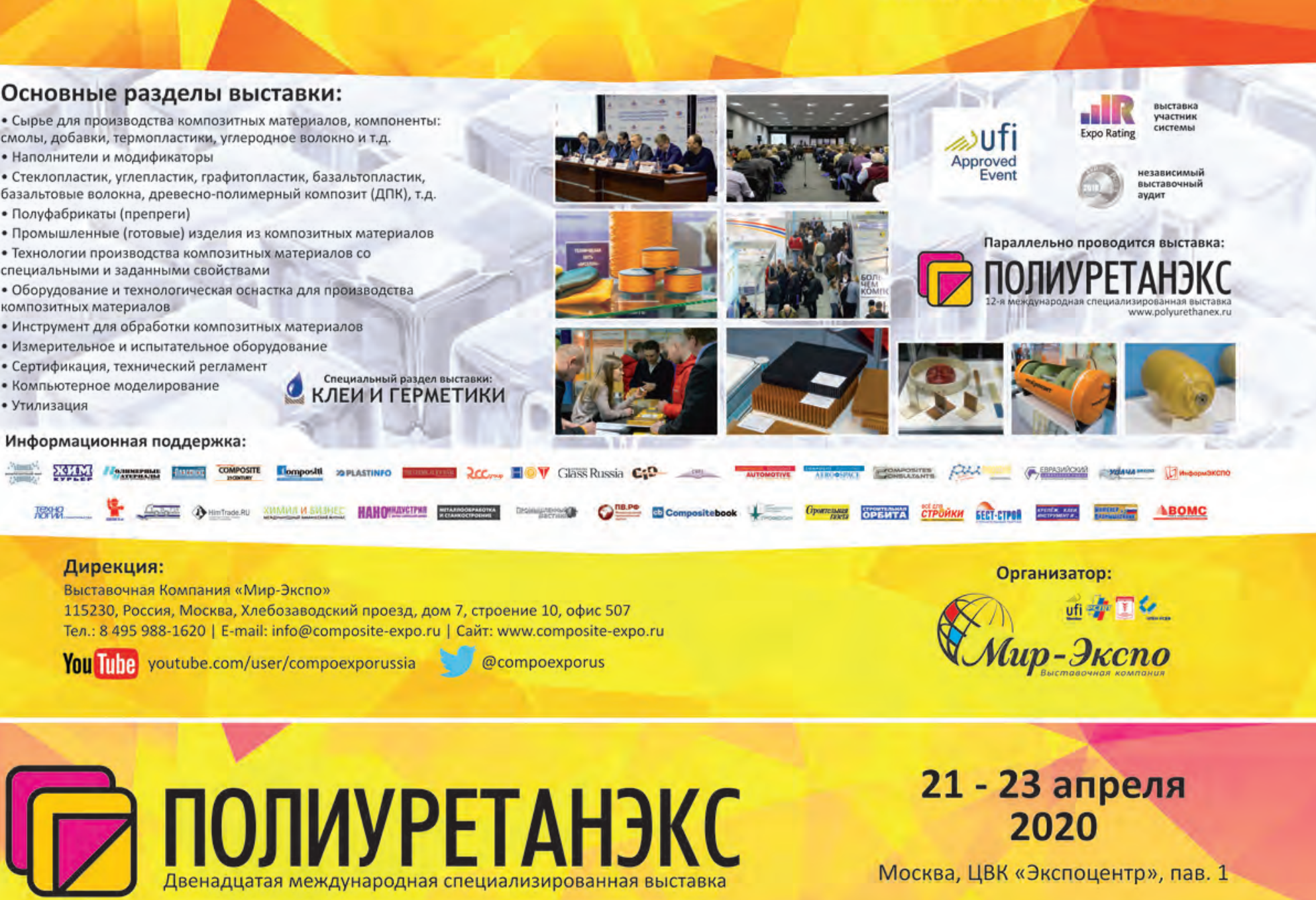

ПОЛИУРЕТА

\section{1 - 23 апреля 2020}

Москва, ЦВК «Экспоцентр», пав. 1

\section{Основные разделы выставки:}

- Сырье для производства полиуретанов

(добавки, красители, катализаторы, наполнители, и т.д.)

- Оборудование и станки для производства и переработки полиуретанов

(расходометрия, шестереночные, оседиагональные (шнековые), шлепперные насосные установки, обрабатывающие станки, и т.д.)

- Конечная продукция

(контактное уплотнение при литье, фильтры и т.д.)

- Услуги

(лабораторные испытания, охрана здоровья и безопастность, переработка, защита окружающей среды, научные разработки)

- Техническое обслуживание оборудования

- Тестовое оборудование

\section{С. Слециальный раздел выставки:}

Информационная поддержка:

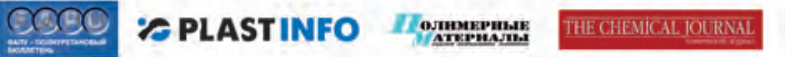
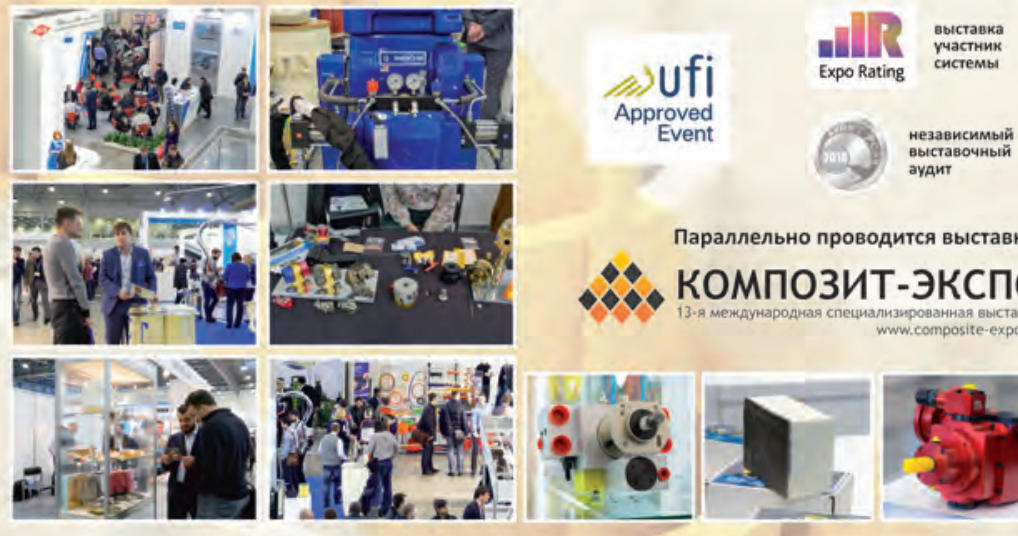

араллельно проводится выставка:

- КОМПОЗИТ-ЭКСПО

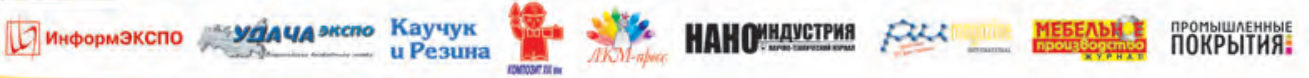
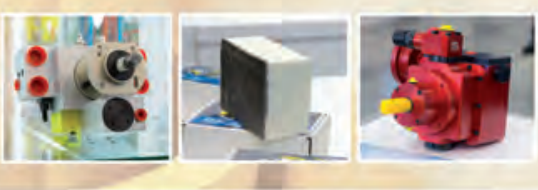

ХАБЕЛЬ

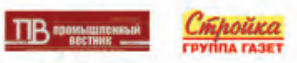

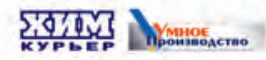

Дирекция:

Выставочная Компания «Мир-Экспо»

115230, Россия, Москва, Хлебозаводский проезд, дом 7, строение 10, офис 507

You Tube
Организатор:

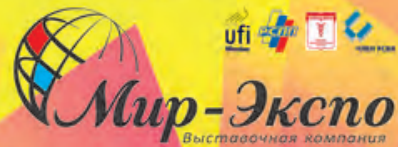

